\title{
Digital Gender Gap Pattern in Indonesia
}

\author{
Anna Puji Lestari ${ }^{\mathrm{a}^{*}}$, Sunarto Sunarto ${ }^{b}$ \\ ${ }^{a}$ Magister Ilmu Komunikasi Universitas Diponegoro, Jl. Erlangga Barat VII No. 33, Semarang, \\ Central Jawa - Indonesia \\ bepartemen Ilmu Komunikasi, FISIP UNDIP, Jl. Prof. H. Soedarto, S.H., Tembalang, Semarang, \\ Central Jawa - Indonesia
}

\begin{abstract}
The development of Communication Technology through the Internet brings a digital gap for women, especially for Baby Boom generation, women who was born in 1946-1964. This study aim to describe the digital gap in family communication. The theory used in this research is Gender Structuration Theory and Liberal Feminist Theory. This research is a descriptive qualitative research with critical phenomenology design. The results suggest that women on Baby Boom generation still marginalized from access to information over the internet due to unequal power on the use of communication technology between female and male family members. That have been happened because of the absence of digital gender awareness of the Y generation (born between 1977 - 1997) to provide internet access and facilities for women on Baby Boom generation who are their mothers. Y Generation prefer to provide internet access and facilities for his father, the Baby Boom man. The provision of means of communication (smart phone) and internet access for baby boom generation is preferred for men. This was due to patriarchal thinking in the pattern of family relationships that assume men have more rights to master communication technology than women.
\end{abstract}

Keywords: Digital Gap; Female; Baby Boom.

\section{Introduction}

The number of internet users continues to increase every year as the expansion of the internet reaches in every region in Indonesia. Based on APJII (Asosiasi Penyelenggara Jasa Internet Indonesia) data, as published on antarajateng.com, the population of the growing community also increase the number of Internet users every time. APJII noted, to date from the total population of the community in Indonesia, the composition of Internet users reached 38 percent. Of the total, about 70 percent are internet users via smart phones, while the rest through broadband. Based on that data, we see the percentage of Internet users are predicted in the future the number will continue to increase.

However, rapid technological developments and the proliferation of smart phones in Indonesia are not enough to encourage women to access the internet and empower women to use technology to access information and make life easier. The digital gap between women and men is still high in Indonesia. The roads to utilize the potential of ICT (information communication technology) to the maximum is still very long for girls and women of low-income residents in the city. In Indonesia, there is no ICT policy, nor the national broadband plan, specifically mentioning gender or the promotion of women's access to the internet and ICT.

Data from ICT Watch as reported by rappler.com states, less than 30 percent of female Internet users use the internet to seek important information about their rights (right to health, reproduction, and law). Based o that research, compared to men, women say that their barrier in accessing the internet is a lack of knowledge. According to the study, women's access to education is one of the main factors determining their level of internet use.

This study examines the use of the Internet by women on Baby Boom generation, as the marginalized generation in

\footnotetext{
Corresponding author: annapujilestari@gmail.com
} 
the middle of the euphoria of the internet. The Baby Boom generation was born after the Second World War from 1946 to 1964. It is called Baby Boom because at that time the increase in the high birth rate as a result of World War II that killed many victims and also make impact on environmental sustainability at that moment because of the demand of supply below human population. This generation is known as a hardworking and idealistic but less adaptive generation [3], and much of the Baby Boomer generation still remains in denial about the likely extent and impact of climate change.

Communication research on the use of communication technology in the Baby Boom generation is still rare so this research contains novelty.

\section{Methodology}

This study uses a critical paradigm. This tradition questions the unequal power relations in the communication process. According to Littlejohn and Fos, the essence of the critical tradition are reveals the oppressive social conditions and oppressive arrangements for the realization of emancipation or the free society of oppression (2008: 46).

This research is a descriptive qualitative research with critical phenomenology design. Data collection techniques were conducted with in-depth interviews. After in-depth interviews, we conduct data reduction with Descriptive Analysis Method with three-phase data analysis process, which are open coding, axial coding, and selective coding.

Critical phenomenology based on study of Merleau-Ponty and Bourdieu. They serve to lay the bases for a critical phenomenology as an attitude that can be adopted in the context of either discipline, but also to defend the position that thinking is always a way to find ourselves in others and others in ourselves (Jerome Melancon, 2014).

According to Bourdieu [1], phenomenology can become explicitly political if it is critical and aware of its political effects. And to do so it must go toward bodies, social structures and the state; it must also enter into a serious relationship with the social sciences. To flesh out the beginnings of a critical phenomenology, we can turn to Maurice Merleau-Ponty (2001: 187), whose treat of the same problems and especially of the social character of thinking anticipated a great part of Bourdieu's criticisms and completes his analyses of the embodied character of thought and of social and political life.

In other words, phenomenology can radicalize itself in order to to push democracy ever further by giving each and everyone the possibility of bringing into question our forced to an order that disadvantages us.

\section{Discussion}

The Baby Boom generation woman who became the informant in this study stated that as a woman (not working), she lacks access to information via the internet. The informant stated that her son, who is already working, has a fixed and sufficient income ( $\mathrm{Y}$ generation, born in 1990) did not want to buy her a smart phone and just wanted to buy a smart phone for his father only (retired civil servants). The informant stated, in fact she wants to have a smart phone like her husband and other friends (male) in order to has WhatsApp and Facebook account and can order online transportation services independently. During this time, she ordered online transportation with the help of her son and the informant felt uncomfortable about that condition because she could not be independent.

Sunarto [2], in Gender Structuration Theory states, in a structure (in this study is the structure of family and society) resources and rules are created and devoted to the interests of men so as to marginalize women. The informant who is a Baby Boomer woman feels marginalized for not getting access to information over the internet.

Thus, that the use of communication technology in the family illustrates the unequal power between female and male family members. Kennedy [4] states, the difference in this pattern is closely related to the distribution of unequal power in the family: between husband and wife, between girl and boy. The implication is that this domestication technology integrates with the division of gender roles in the family [5].

Research on internet gap usage between men and women need to be applied with feminism approach to see social bias in society. The feminist approach considers the historical and political background in Indonesia which tends to highlight the domestic role of women (patriarchy culture).

The legitimacy of the patriarchal culture has in fact put women at a very disadvantaged position in life including access to Internet-based information. Women get an unequal position in terms of digital technology. Liberal Feminists oppose such views. The objective of Liberal Feminists is the creation of a society of mutual respect and always having developed freedom.

Liberal Feminists voice the same education for women and men. Wollstonecraft, the Liberal Feminist, opposes the thought of Jean-Jacques Rousseau stating that education for men was created to achieve maximum effort to achieve goals and justice. While education for women should teach patience and obedience. Therefore, according to Rousseau, education suitable for men is a lesson about humanities, natural sciences and social sciences. While lessons that are suitable for women are art, music, fiction,

\footnotetext{
*Corresponding author: annapujilestari@gmail.com
} 
poetry. This then makes men as extreme beings narcissistic, hypersensitive, and want to be spoiled excessively (in Tong, 2008: 18). Liberal Feminists argue that the low participation of women in science and technology can be accomplished by providing equal access to education for women [6]. Digital Gender gap in Indonesia is still happening in Indonesia until now because of patriarchy culture which assume that education about ICT is only for men.

\section{Conclusion}

Gender gap disconnects women from technology. Since childhood, women do not have the same opportunities as men in technology. The main obstacle is that women in developing countries, especially women of Baby Boom generation do not have adequate knowledge and affordability as stated by informant in this research. Global facts show that it is rooted in the social factor of patriarchal culture, there is still a gender gap which eventually breaks women from technology. Since childhood, women are not given the same opportunities as boys in technological means.

\section{References}

1. P. Bourdieu, The Political ontology of Martin Heidegger, Stanford: Stanford University Press, (1991).

2. Sunarto, Televisi, Kekerasan, dan Perempuan, Jakarta: Kompas, (2009).

3. D. Agung, Kebutuhan Layanan Internet di Jateng Meningkat, Retrieved on October 26, 2017 from https://tirto.id/kebutuhan-layanan-internet-di-jatengmeningkat-b91q (2016).
4. T.L.M. Kennedy, Gender and the Household Internet, Encyclopedia of Gender and Information Technology, IGI Global, (2006).

5. J. Ahrens, Going Online, Doing Gender: Everyday Practices Around the Internet in Germany and Australia, Germany: Bielefeld. (2009).

6. J. Wacjman, Feminist Theories of Technology, Cambridge Journal of Economic, (2009).

7. Anonim, Kesenjangan Digital Antara Perempuan dan Laki-laki Masih Tinggi di Indonesia, Retrieved on October 26, 2017 from https://www.rappler.com/indonesia/110310-kesenjangandigital-antara-perempuan-dan-laki-laki-masih-tinggi-diindonesia (2014).

8. P. Poindexter, S. Meraz, A. Schmitz Weiss (eds.), Women, Men, and News: Divided and Disconnected in the News Media Landscap, New York: Routledge (2008).

9. Littlejohn, W. Stephen, A. Foss Karen, Theories of Human Communication, 9th edition, USA: Thompson Wadsworth, (2008).

10. M. Merleau-Ponty, Humanism and Terror, Boston: Beacon Press, (2001).

11. T. R. Putnam, Feminis Thought: Pengantar Paling Komprehensif kepada Aliran Utama Pemikiran Feminis (Terj., Yogyakarta: Jalasutra. (2008).

12. The Guardian, Will Generation Zero Clean Up the Baby Boomers Environmental Mass?, (2011), retrieved at https://www.theguardian.com/sustainablebusiness/sustainability-with-john-elkington/generationzero-baby-boomers-environmental-mess

\footnotetext{
*Corresponding author: annapujilestari@gmail.com
} 